Check for updates

Cite this: RSC Adv., 2020, 10, 16882

Received 2nd April 2020

Accepted 21st April 2020

DOI: $10.1039 / \mathrm{dOra02994 \textrm {g }}$

rsc.li/rsc-advances

\section{Concise asymmetric synthesis of two natural oxacyclododecindione-type macrolactones from industrial waste $\uparrow$}

\author{
Xian Liu, Huifang Nie, Lin Yao, Ru Jiang (D) * and Weiping Chen (D)* \\ (S)-5-Methyl-tetrahydropyran-2-one 1 is a by-product in the production of key intermediates of steroidal \\ hormones. Asymmetric synthesis of natural oxacyclododecindione-type macrolactones 2 and 3 has been \\ realized for the first time from (S)-1 in seven and eight steps with $37 \%$ and $27 \%$ overall yield, respectively.
}

\section{Introduction}

Green chemistry, which was established about two decades ago, has attracted considerable attention due to its reduction or elimination of the use and generation of hazardous substances from a chemical process. ${ }^{1}$ Most efforts have focused on waste minimization and avoiding the use of toxic or hazardous reagents and solvents, particularly in the pharmaceutical field. However, little attention has been paid on the rational reuse of industrial wastes. ${ }^{2}$ Both $(R)$ - and $(S)$-5-methyl-tetrahydropyran-2one 1 are by-products in the production of key intermediates (16-dehydropregnenolone derivatives) of steroidal hormones from steroidal sapogenins by oxidative degradation (Scheme 1). ${ }^{3}$ To produce $100 \mathrm{~kg}$ of 16-dehydropregnenolone derivatives may generate more than $30 \mathrm{~kg}$ of $(R)$ - or $(S)-\mathbf{1}$ as wastes, ${ }^{3 \boldsymbol{b}}$ and almost all of them are destroyed by burning or other methods. ${ }^{4}$ At present, the throughput of 16-dehydropregnenolone derivatives is kiloton each year only in China. There have been only very few examples to utilize $(R)$ - and $(S)-\mathbf{1}$ as starting materials in the synthesis of bioactive compounds. ${ }^{5}$ Therefore, exploiting the synthesis application of $(R)$ - or $(S)-\mathbf{1}$ is highly welcomed.

In 2008, three new 12-membered macrolactones 4-dechloro14-deoxy-oxacyclododecindione 2, 14-deoxy-oxacylododecin-

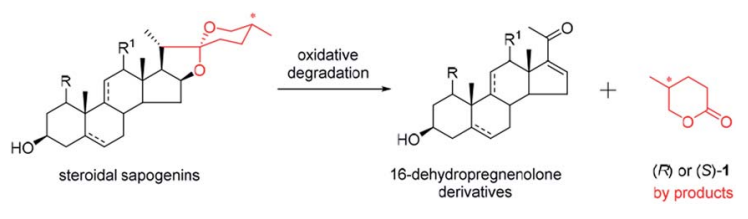

Scheme 1 Production of industrial wastes (R)- and (S)-1.

School of Pharmacy, Fourth Military Medical University, 169 Changle West Road, Xian, 710032, P. R. China. E-mail: jiangru@fmmu.edu.cn

$\dagger$ Electronic supplementary information (ESI) available. See DOI: 10.1039/d0ra02994g dione 3 and oxacyclododecindione $\mathbf{4}$ were isolated as fungal secondary metabolites from imperfect fungus Exserohilum rostratum by Opatz and Erkel (Fig. 1). ${ }^{6 a}$ They exhibit potent antiinflammatory and anti-fibrotic activities in cell culture experiments and in an in vivo mouse model of systemic lupus erythematosus (SLE) and may serve as lead structures for therapeutics against chronic inflammatory and/or fibrotic diseases like asthma, rheumatoid arthritis, SLE or cancer. ${ }^{6}$ In 2005, Opatz attempted to finish the total synthesis of racemic 2 and $3 .^{7}$ Starting from commercially available cis-2,3-epoxybutane and allyl cuprate, the total synthesis of racemic $2(24 \%$ yield over 10 steps) and 3 (18\% yield over 11 steps) was accomplished by important steps such as ring-opening reaction, witting reaction, and a late-stage intramolecular FriedelCrafts cyclization. ${ }^{7 \boldsymbol{a}}$ Protection and deprotection reactions are frequently used in the total synthesis of racemic 2 and 3 which made the synthesis route more complicated and led to a lower overall yield. Soon after, the absolute configuration of natural 2 and 3 was determined as $(14 S, 15 R)$ by X-ray crystallography. ${ }^{8}$ To date, the asymmetric synthesis of natural macrolactones $\mathbf{2}$ and 3 is still an untouched work.

Our retrosynthetic strategy for the synthesis of $(14 S, 15 R)-2$ commences with the disconnection of the C8-C9 bond, exposing tert-butyl ester ( $6 S, 7 R, E)-5$ (Scheme 2). We envisioned that the intramolecular Friedel-Crafts cyclization of 5 in the presence of Lewis acid could form $(14 S, 15 R)-2$, meanwhile the cleavage of tert-butyl ester bond could be simultaneously achieved. Tert-butyl ester $\mathbf{5}$ could be easily generated by esterification of arylacetic acid 6 and alcohol $(6 S, 7 R, E)-7$. We envisioned
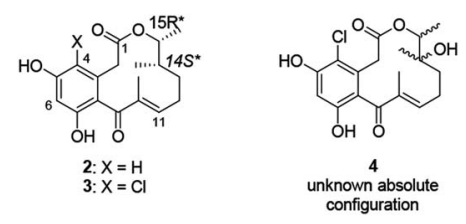

Fig. 1 Structures of the oxacyclododecindiones 2, 3 and 4 . 


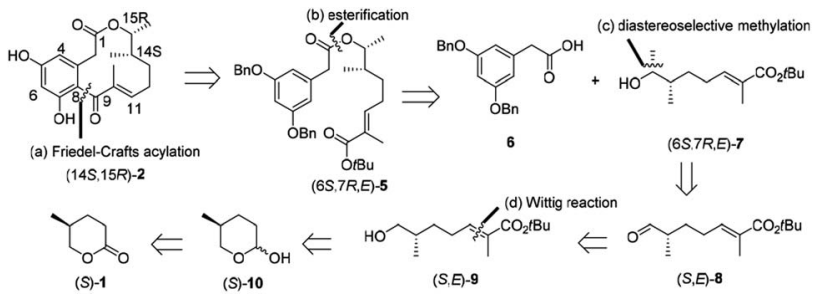

Scheme 2 Retrosynthetic analysis of $(14 S, 15 R)-2$ by (a) an intramolecular Friedel-Crafts acylation, (b) an esterification, (c) a diastereoselective methylation, and (d) a Wittig reaction.

that the key alcohol intermediate $(6 S, 7 R, E)-7$ could be obtained from aldehyde $(S, E)$-8 by diastereoselective methylation, while the stereogenic center at $\mathrm{C} 7$ could be constructed according to Kovalenko and Matiushenkov's procedure. ${ }^{9}(S, E)-8$ could be readily prepared by a sequential reduction, Wittig reaction and oxidation from $(S)$-1. Based on the retrosynthetic analysis, herein, we reported the first asymmetric total synthesis of natural $(14 S, 15 R)-2$ and $(14 S, 15 R)-3$ starting from abundant and renewable industrial waste $(S)-\mathbf{1}$.

\section{Results and discussion}

With the synthetic blueprint in mind, our initial attention was focused on preparation of the key intermediate $(6 S, 7 R, E)-7$ (Scheme 3). As depicted in Scheme 3, reduction of $(S)-\mathbf{1}$ with DIBAL-H furnished the corresponding lactol $(S)-\mathbf{1 0}$, which was subjected to a Wittig reaction with ylide 11 (ref. 10) without further purification to give $(S, E)-9$ in $82 \%$ yield with $\mathrm{E}: Z>95: 5$ selectivity. TEMPO-mediated-oxidation of $(S, E)-9$ employing $\mathrm{PhI}(\mathrm{OAc})_{2}$ as a secondary oxidant, which is compatible with the presence of olefins, ${ }^{11}$ afforded the corresponding aldehyde $(S, E)$ 8 in $84 \%$ yield. Next, according to Kovalenko and Matiushenkov's procedure, $(S, E)-\mathbf{8}$ was diastereoselectively methylated with $\mathrm{MeTi}(\mathrm{O} i \mathrm{Pr})_{3}$ (ref. 12) in the presence of $20 \mathrm{~mol} \%$ of TADDOL-Ti $(\mathrm{O} i \mathrm{Pr})_{2}$. Unfortunately, when $[(S, S)$-TADDOL $] \mathrm{Ti}(\mathrm{O} i \mathrm{Pr})_{2}$ was used as catalyst, the methylation of $(S, E)-8$ gave an inseparable mixture of two diastereomers $(6 S, 7 R, E)-7$ and $(6 S, 7 S, E)-7$ with d.r. $76: 24$ (the ratio of a peak of protons on C8 for $(6 S, 7 S, E)-7$ at $1.17 \mathrm{ppm}$ and $(6 S, 7 R, E)-7$ at $1.14 \mathrm{ppm})$. To our delight, in the presence of $[(R, R)$-TADDOL $] \mathrm{Ti}(\mathrm{O} i \mathrm{Pr})_{2},(6 S, 7 S, E)-7$ was obtained in $94 \%$ yield with d.r. > $95: 5$ (the signal of

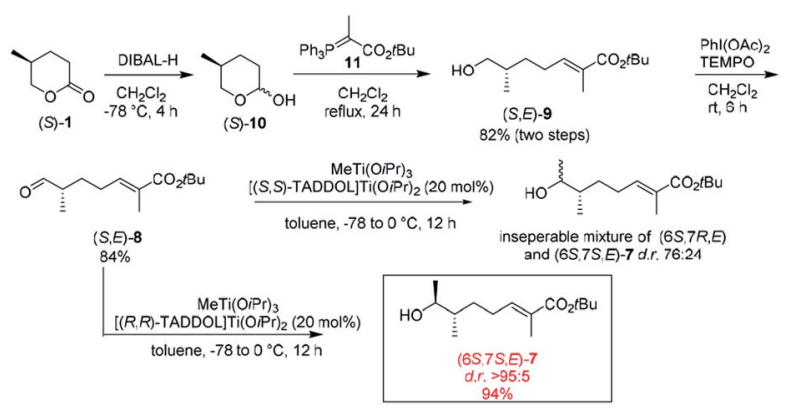

Scheme 3 Synthesis of key intermediate $(6 S, 7 S, E)-7$.

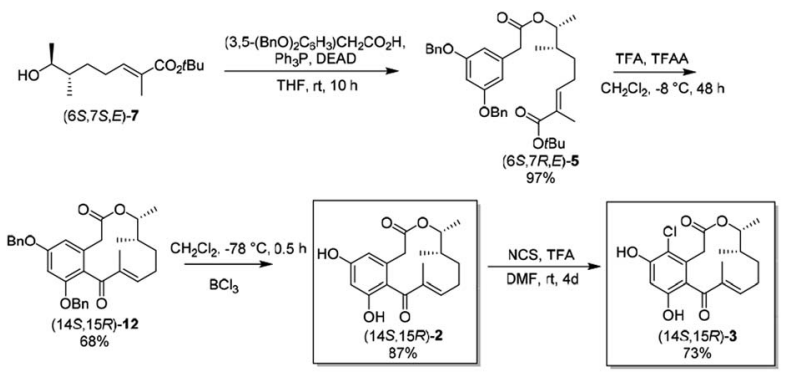

Scheme 4 Synthesis of (14S,15R)-2 and (14S,15R)-3 from $(6 S, 7 S, E)-7$.

$(6 S, 7 R, E)-7$ was undetectable in ${ }^{1} \mathrm{H}$ NMR). Although the configuration at $\mathrm{C} 7$ was opposite to that of key intermediates $(6 S, 7 R, E)-7$, it could be converted by Mitsunobu reaction. Therefore, the next synthesis route was adjusted as Scheme 4 .

Reaction of $(6 S, 7 S, E)-7$ with 3,5-bis(benzyloxy)phenylacetic acid under Mitsunobu reaction conditions gave ester $(6 S, 7 R, E)-\mathbf{5}$ in $97 \%$ yield. As we expected, when the diluted solution of $(6 S, 7 R, E)-5$ in $\mathrm{CH}_{2} \mathrm{Cl}_{2}$ was treated with a mixture of trifluoroacetic anhydride and trifluoroacetic acid, the cleavage of the tert-butyl ester bond and intramolecular Friedel-Crafts acylation took place simultaneously to give the desired lactone $(14 S, 15 R)-12$ in $68 \%$ yield. Finally, deprotection of the benzyl ethers with boron trichloride afforded $(14 S, 15 R)-2$ in $87 \%$ yield, which was further converted to $(14 S, 15 R)-3$ (in $73 \%$ yield) by chlorination with $N$-chlorosuccinimide. ${ }^{1} \mathrm{H}$ and ${ }^{13} \mathrm{C}$ NMR spectra of both synthetic $(14 S, 15 R)-2$ and $(14 S, 15 R)-3$ were in good agreement with the data of the natural products. ${ }^{8}$

\section{Conclusions}

In summary, concise and efficient asymmetric total synthesis of natural 4-dechloro-14-deoxy-oxacyclododecindione 2 and 14deoxy-oxacylododecindione 3 has been accomplished for the first time. Using industrial waste $(S)$-5-methyl-tetrahydropyran2-one 1 as starting material, $(14 S, 15 R)-2$ and 3 were obtained in seven and eight steps with $37 \%$ and $27 \%$ overall yield, respectively. The chirality of $\mathrm{C} 14$ originates from the starting material, and the stereogenic center at C15 is stereospecifically constructed by highly diastereoselective methylation and Mitsunobu reaction.

\section{Experimental section}

\section{General methods}

Unless otherwise noted, all reactions sensitive to air or moisture were performed under nitrogen atmosphere. All commercially available chemicals including solvents were used without further purification. (S)-5-Methyl-tetrahydropyran-2-one $(S)$-1 was prepared from sarsasapogenin according to Tian's procedure. ${ }^{3 b}$ NMR spectra were recorded on Bruker 400 spectrometer. ${ }^{1} \mathrm{H}$ NMR and ${ }^{13} \mathrm{C}$ NMR spectra were measured at $400 \mathrm{MHz}$ and $101 \mathrm{MHz}$. High resolution mass measurements (HRMS) were obtained on Bruker smart apex II. Optical rotations were measured on the PerkinElmer 343 polarimeter. 
(S,E)-tert-Butyl 7-hydroxy-2,6-dimethylhept-2-enoate (S,E)-9. To a stirred solution of $(S)-\mathbf{1}(3.00 \mathrm{~g}, 26.32 \mathrm{mmol})$ in dry $\mathrm{CH}_{2} \mathrm{Cl}_{2}$ $(20 \mathrm{~mL})$ was added DIBAL-H $(1.0 \mathrm{M}$ in hexane, $26.3 \mathrm{~mL}, 26.3$ $\mathrm{mmol})$ at $-78{ }^{\circ} \mathrm{C}$. After $4 \mathrm{~h}$ stirring at the same temperature, saturated Rochelle salt $(15 \mathrm{~mL})$ was added and further stirred for $6 \mathrm{~h}$ at room temperature. The mixture was extracted with $\mathrm{CH}_{2} \mathrm{Cl}_{2}$, dried over anhydrous $\mathrm{Na}_{2} \mathrm{SO}_{4}$, and evaporated to give the corresponding lactol $(S)$-10 as a yellow oil ( $2.51 \mathrm{~g}$ ), which was used directly without purification. The crude product was added to the solution of tert-butyl 2-(triphenylphosphoranylidene) propanoate $(12.52 \mathrm{~g}, 32.07 \mathrm{~mol})$ in $\mathrm{CH}_{2} \mathrm{Cl}_{2}(20 \mathrm{~mL})$. After being refluxed for $24 \mathrm{~h}$, the solvent was removed in vacuo. Purification by flash chromatography on silica gel (petroleum ether : EtOAc $=5: 1)$ yielded $(S, E)-9(4.91 \mathrm{~g}, 82 \%) \cdot[\alpha]_{\mathrm{D}}^{20}=-11.1(c 0.31$, $\left.\mathrm{CH}_{2} \mathrm{Cl}_{2}\right) .{ }^{1} \mathrm{H}$ NMR $\left(400 \mathrm{MHz}, \mathrm{CDCl}_{3}\right): \delta 6.65(\mathrm{t}, J=1.2 \mathrm{~Hz}, 1 \mathrm{H})$, 3.54-3.44 (m, 2H), 2.33-2.05 (m, 2H), $1.79(\mathrm{~s}, 3 \mathrm{H}), 1.68-1.54(\mathrm{~m}$, 2H), $1.48(\mathrm{~s}, 9 \mathrm{H}), 1.32-1.26(\mathrm{~m}, 1 \mathrm{H}), 0.95(\mathrm{~d}, J=6.7 \mathrm{~Hz}, 3 \mathrm{H}) .{ }^{13} \mathrm{C}$ NMR (101 MHz, $\left.\mathrm{CDCl}_{3}\right): \delta$ 167.6, 140.9, 129.2, 80.0, 68.1, 35.4, 32.0, 28.1, 26.1, 16.4, 12.4. HRMS (ESI): calcd for $\left[\mathrm{C}_{13} \mathrm{H}_{24} \mathrm{O}_{3}+\right.$ $\left.\mathrm{Na}^{+}\right]: 251.1618$, found: 251.1620 .

$(6 S, 7 S, E)$-tert-Butyl-7-hydroxy-2,6-dimethyloct-2-enoate (6S, 7S,E)-7. Step 1: a solution of alcohol $(S, E)-9(3.00 \mathrm{~g}, 13.16 \mathrm{mmol})$, iodobenzene diacetate $(4.6 \mathrm{~g}, 14.28 \mathrm{mmol})$ and 2,2,6,6-tetramethylpiperidinooxy ( $205 \mathrm{mg}, 1.31 \mathrm{mmol}$ ) in $\mathrm{CH}_{2} \mathrm{Cl}_{2}(26 \mathrm{~mL}, 0.5$ $\mathrm{M})$ was stirred at room temperature. After stirring for $3 \mathrm{~h}$, the reaction mixture is washed successively with an aqueous sodium thiosulfate solution and brine. The organic solution is dried over anhydrous $\mathrm{Na}_{2} \mathrm{SO}_{4}$, and concentrated. Purification by flash chromatography on silica gel (petroleum ether : EtOAc $=$ $10: 1)$ yielded the $(S, E)-8(2.50 \mathrm{~g}, 84 \%)$ as a light red oil which was used immediately. Step 2: a solution of $((4 R, 5 R)-2,2-$ dimethyl-1,3-dioxolane-4,5-diyl)bis(di-phenyl-methanol) $[(R, R)$ TADDOL] (488 mg, $1.05 \mathrm{mmol})$ and $\mathrm{Ti}(\mathrm{O} i \mathrm{Pr})_{4}(446 \mathrm{mg}, 1.57$ $\mathrm{mmol})$ in toluene $(8 \mathrm{~mL})$ was heated at $110{ }^{\circ} \mathrm{C}$ for $3 \mathrm{~h}$ under an argon atmosphere. The solvent was removed in vacuo, after which the residue was diluted with dry toluene $(28 \mathrm{~mL})$ in $-78{ }^{\circ} \mathrm{C}$ mixed with $\mathrm{MeTi}(\mathrm{O} i \mathrm{Pr})_{3}(1.88 \mathrm{~g}, 7.84 \mathrm{mmol})$ and stirred at the same temperature for $0.5 \mathrm{~h}$. The aldehyde $(S, E)-8(1.18 \mathrm{~g}$, $5.23 \mathrm{mmol})$ in toluene $(3 \mathrm{~mL})$ was added dropwise to the resulting stirred solution at $-78{ }^{\circ} \mathrm{C}$. The mixture was stirred for $12 \mathrm{~h}$ at $-78{ }^{\circ} \mathrm{C}$ and then gradually warmed to $0{ }^{\circ} \mathrm{C}$ for $12 \mathrm{~h}$, diluted with saturated aqueous $\mathrm{NH}_{4} \mathrm{Cl}(5 \mathrm{~mL})$, and filtered. The filter cake was washed with $\mathrm{CH}_{2} \mathrm{Cl}_{2}$. The organic phase was separated and washed with saturated aqueous $\mathrm{NaHCO}_{3}$, dried over anhydrous $\mathrm{Na}_{2} \mathrm{SO}_{4}$. The solvent was removed in vacuo. Purification by flash chromatography on silica gel (petroleum ether : EtOAc $=10: 1)$ yielded $(6 S, 7 S, E)-7(1.20 \mathrm{~g}, 94 \%)$ with d.r. $>95: 5 .[\alpha]_{\mathrm{D}}^{20}=-18.5\left(c 1.27, \mathrm{CH}_{2} \mathrm{Cl}_{2}\right) \cdot{ }^{1} \mathrm{H}$ NMR $(400 \mathrm{MHz}$, $\left.\mathrm{CDCl}_{3}\right): \delta 6.65(\mathrm{td}, J=7.4,1.4 \mathrm{~Hz}, 1 \mathrm{H}), 3.77-3.71(\mathrm{~m}, 1 \mathrm{H}), 2.22-$ $2.11(\mathrm{~m}, 2 \mathrm{H}), 1.79(\mathrm{~s}, 3 \mathrm{H}), 1.62-1.56(\mathrm{~m}, 1 \mathrm{H}), 1.49(\mathrm{~s}, 9 \mathrm{H}), 1.32-$ $1.25(\mathrm{~m}, 2 \mathrm{H}), 1.17(\mathrm{~d}, J=6.4 \mathrm{~Hz}, 3 \mathrm{H}), 0.92(\mathrm{~d}, J=6.8 \mathrm{~Hz}, 3 \mathrm{H}) .{ }^{13} \mathrm{C}$ NMR $\left(101 \mathrm{MHz}, \mathrm{CDCl}_{3}\right): \delta 167.6,141.0,129.2,80.0,71.2,39.4$, 31.5, 28.2, 26.5, 20.3, 14.0, 12.4. HRMS (ESI): calcd for $\left[\mathrm{C}_{36} \mathrm{H}_{44} \mathrm{O}_{6}\right.$ $\left.+\mathrm{Na}^{+}\right]: 265.1774$, found: 265.1775 .

(6S,7R,E)-tert-Butyl-7-(2-(3,5-bis(benzyloxy)phenyl)acetoxy)2,6-dimethyloct-2-enoate $(6 S, 7 R, E)-5$. To a solution of $(6 R, 7 R, E)$ -
7 (100 mg, $0.41 \mathrm{mmol}$ ), 3,5-bis(benzyloxy)phenylacetic acid (216 mg, $0.62 \mathrm{mmol})$, and triphenylphosphine (163 mg, 0.62 $\mathrm{mmol})$ in THF $(1.2 \mathrm{~mL})$ was added dropwise a THF $(1 \mathrm{~mL})$ solution of diisopropyl azodicarboxylate $(125 \mathrm{mg}, 0.62 \mathrm{mmol})$. After stirring for $10 \mathrm{~h}$ at room temperature, the solvent was removed in vacuo. Purification by column chromatography on silica gel (petroleum ether : EtOAc $=20: 1$ ) yielded $(6 R, 7 S, E)-5$ $(230 \mathrm{mg}, 97 \%)$ as a colorless oil. $[\alpha]_{\mathrm{D}}^{20}=-5.6\left(c 0.60, \mathrm{CH}_{2} \mathrm{Cl}_{2}\right) .{ }^{1} \mathrm{H}$ NMR (400 MHz, $\left.\mathrm{CDCl}_{3}\right): \delta 7.49-7.29(\mathrm{~m}, 10 \mathrm{H}), 6.65-6.49(\mathrm{~m}$, $4 \mathrm{H}), 5.02(\mathrm{~s}, 4 \mathrm{H}), 4.89-4.76(\mathrm{~m}, 1 \mathrm{H}), 3.53(\mathrm{~s}, 2 \mathrm{H}), 2.26-1.98(\mathrm{~m}$, $2 \mathrm{H}), 1.77(\mathrm{~s}, 3 \mathrm{H}), 1.73-1.60(\mathrm{~m}, 1 \mathrm{H}), 1.47(\mathrm{~s}, 9 \mathrm{H}), 1.27-1.15(\mathrm{~m}$, $2 \mathrm{H}), 1.13(\mathrm{~d}, J=6.4 \mathrm{~Hz}, 3 \mathrm{H}), 0.88(\mathrm{~d}, J=6.8 \mathrm{~Hz}, 3 \mathrm{H}) .{ }^{13} \mathrm{C} \mathrm{NMR}$ $\left(101 \mathrm{MHz}, \mathrm{CDCl}_{3}\right): \delta 170.9,167.5,160.0,140.6,136.9,136.4$, 129.4, 128.6, 128.0, 127.5, 108.5, 100.84, 80.0, 74.5, 70.0, 42.0, 37.1, 31.3, 28.1, 26.2, 16.0, 14.6, 12.4. HRMS (ESI): calcd for $\left[\mathrm{C}_{36} \mathrm{H}_{44} \mathrm{O}_{6}+\mathrm{Na}^{+}\right]: 595.3030$, found: 595.3014.

(14S,15R)-5,7-Di-O-benzyl-4-dechloro-14-deoxyoxacyclododecindione (14S,15R)-12. $(6 S, 7 R, E)-5(928 \mathrm{mg}, 1.62 \mathrm{mmol})$, trifluoroacetic acid $(167 \mathrm{~mL})$ and trifluoroacetic anhydride $(83.5$ $\mathrm{mL}$ ) were dissolved in $\mathrm{CH}_{2} \mathrm{Cl}_{2}(2100 \mathrm{~mL})$ and cooled to $-8 \mathrm{C}$. The reaction mixture stood at $-8{ }^{\circ} \mathrm{C}$ for $48 \mathrm{~h}$. The solvent was removed in vacuo. Purification by flash chromatography on silica gel (petroleum ether : EtOAc $=15: 1)$ yielded $(14 S, 15 R)-12$ $(545 \mathrm{mg}, 68 \%)$ as a colorless oil. $[\alpha]_{\mathrm{D}}^{20}=+36.6\left(c 0.20, \mathrm{CH}_{2} \mathrm{Cl}_{2}\right)$. ${ }^{1} \mathrm{H}$ NMR $\left(400 \mathrm{MHz}, \mathrm{CDCl}_{3}\right): \delta 7.65-7.07(\mathrm{~m}, 10 \mathrm{H}), 6.51(\mathrm{~d}, J=$ $1.3 \mathrm{~Hz}, 3 \mathrm{H}), 5.17-4.90(\mathrm{~m}, 4 \mathrm{H}), 4.59(\mathrm{dq}, J=12.7,6.2 \mathrm{~Hz}, 1 \mathrm{H})$, $3.31(\mathrm{t}, J=13.5 \mathrm{~Hz}, 2 \mathrm{H}), 2.42(\mathrm{~s}, 1 \mathrm{H}), 2.11(\mathrm{~d}, J=20.3 \mathrm{~Hz}, 1 \mathrm{H})$, $1.93(\mathrm{~s}, 3 \mathrm{H}), 1.69-1.60(\mathrm{~m}, 1 \mathrm{H}), 1.53-1.31(\mathrm{~m}, 2 \mathrm{H}), 1.09(\mathrm{~d}, J=$ $4.6 \mathrm{~Hz}, 3 \mathrm{H}), 0.92(\mathrm{~d}, J=7.0 \mathrm{~Hz}, 3 \mathrm{H}) .{ }^{13} \mathrm{C} \mathrm{NMR}\left(101 \mathrm{MHz}, \mathrm{CDCl}_{3}\right)$ : $\delta$ 199.3, 170.4, 159.9, 156.6, 152.9, 136.9, 136.7, 133.3, 128.8, 128.6, 128.2, 127.8, 127.8, 127.7, 126.9, 124.3, 107.7, 100.4, 77.3, 70.4, 70.3, 53.6, 39.7, 19.2, 10.5. HRMS (ESI): calcd for $\left[\mathrm{C}_{32} \mathrm{H}_{34} \mathrm{O}_{5}\right.$ $+\mathrm{Na}^{+}$]: 521.2298, found: 521.2294.

$(14 S, 15 R)$-4-Dechloro-14-deoxyoxacyclododecindione (14S, 15R)-2. A solution of $(14 S, 15 R)-12(460 \mathrm{mg}, 0.923 \mathrm{mmol})$ in $\mathrm{CH}_{2} \mathrm{Cl}_{2}(138 \mathrm{~mL})$ was cooled to $-78^{\circ} \mathrm{C}$. Boron trichloride $(1.0 \mathrm{M}$ in hexane, $9.3 \mathrm{~mL}, 9.3 \mathrm{mmol}$ ) was added and the mixture was stirred at that temperature. After $30 \mathrm{~min}$ the reaction mixture was quenched with saturated aqueous $\mathrm{NaHCO}_{3}(50 \mathrm{~mL})$ and warmed up to room temperature. The organic layer was separated and the aqueous layer was extracted with $\mathrm{CH}_{2} \mathrm{Cl}_{2}$. The combined organic layers were dried over anhydrous $\mathrm{Na}_{2} \mathrm{SO}_{4}$ and filtered. The solvent was removed in vacuo. Purification by flash chromatography on silica gel (petroleum ether : EtOAc $=2: 1$ ) yielded $(14 S, 15 R)-2(256 \mathrm{mg}, 87 \%)$ as a white solid. $[\alpha]_{\mathrm{D}}^{20}=+41.5$ $(c 0.3, \mathrm{MeOH})$ lit. $[\alpha]_{\mathrm{D}}^{20}=+29.1(c 0.40, \mathrm{MeOH}) .{ }^{1} \mathrm{H}$ NMR $(400$ $\mathrm{MHz}, \mathrm{MeOD}): \delta 6.52(\mathrm{~s}, 1 \mathrm{H}), 6.30(\mathrm{~s}, 1 \mathrm{H}), 6.26(\mathrm{~s}, 1 \mathrm{H}), 4.67-4.50$ $(\mathrm{m}, 1 \mathrm{H}), 3.23(\mathrm{t}, J=16.3 \mathrm{~Hz}, 2 \mathrm{H}), 2.48-2.42(\mathrm{~m}, 1 \mathrm{H}), 2.25-2.21$ $(\mathrm{m}, 1 \mathrm{H}), 1.88(\mathrm{~s}, 3 \mathrm{H}), 1.70(\mathrm{dd}, J=14.1,7.8 \mathrm{~Hz}, 1 \mathrm{H}), 1.56(\mathrm{dd}, J=$ $13.7,6.9 \mathrm{~Hz}, 1 \mathrm{H}), 1.49-1.37(\mathrm{~m}, 1 \mathrm{H}), 1.13(\mathrm{~d}, J=6.1 \mathrm{~Hz}, 3 \mathrm{H}), 0.93$ (d, $J=7.0 \mathrm{~Hz}, 3 \mathrm{H}) .{ }^{13} \mathrm{C}$ NMR (101 MHz, MeOD): $\delta 203.1,172.1$, $160.2,157.5,154.1,138.1,134.8,120.9,109.6,102.5,78.2,40.8$ 40.4, 34.3, 29.7, 19.5, 19.4, 10.6. HRMS (ESI): calcd for $\left[\mathrm{C}_{18} \mathrm{H}_{22} \mathrm{O}_{5}\right.$ $\left.+\mathrm{Na}^{+}\right]$: 341.1359, found: 341.0360 .

$(14 S, 15 R)$-4-Deoxyoxacyclododecindione (14S,15R)-3. Lactone $(14 S, 15 R)-2(120 \mathrm{mg}, 0.38 \mathrm{mmol})$ and $N$-chlorosuccinimide $(51 \mathrm{mg}, 0.38 \mathrm{mmol})$ were dissolved in dry DMF $(15 \mathrm{~mL})$ and 
trifluoroacetic acid ( $41 \mu \mathrm{L}, 0.57 \mathrm{mmol})$ was added. The reaction mixture was stirred at room temperature for 4 days. The solvent was removed in vacuo. Purification by flash chromatography on silica gel (petroleum ether : EtOAc $=2: 1$ ) yielded $(14 R, 15 R)-2$ (98 mg, 73\%) as a white solid. $(14 S, 15 R)-3:[\alpha]_{\mathrm{D}}^{20}=+18.6(c 0.30$, $\mathrm{MeOH})$ lit. $[\alpha]_{\mathrm{D}}^{20}=+9.6\left(c 0.34, \mathrm{CD}_{3} \mathrm{OD}\right) .{ }^{1} \mathrm{H}$ NMR $(400 \mathrm{MHz}$, $\left.\mathrm{CD}_{3} \mathrm{CN}\right): \delta 7.44(\mathrm{~s}, 2 \mathrm{H}), 6.65(\mathrm{~d}, J=7.8 \mathrm{~Hz}, 1 \mathrm{H}), 6.50(\mathrm{~s}, 1 \mathrm{H}), 4.64-$ $4.57(\mathrm{~m}, 1 \mathrm{H}), 3.54(\mathrm{~d}, J=17.1 \mathrm{~Hz}, 1 \mathrm{H}), 3.23(\mathrm{~d}, J=17.2 \mathrm{~Hz}, 1 \mathrm{H})$, 2.53 (dd, $J=18.1,11.9 \mathrm{~Hz}, 1 \mathrm{H}), 2.05-1.97$ (m, 1H), 1.83 (s, 3H), 1.69-1.57 (m, 1H), 1.55-1.50 (m, 1H), 1.31-1.21 (m, 1H), 1.07 (d, $J$ $=6.2 \mathrm{~Hz}, 3 \mathrm{H}), 0.90(\mathrm{~d}, J=7.1 \mathrm{~Hz}, 3 \mathrm{H}) .{ }^{13} \mathrm{C} \mathrm{NMR}(101 \mathrm{MHz}$, $\left.\mathrm{CD}_{3} \mathrm{CN}\right): \delta 200.0,169.6,154.9,154.8,153.0,137.8,133.4,123.3$, 114.2, 103.9, 77.6, 40.0, 39.4, 34.8, 29.7, 19.7, 19.6, 10.8. HRMS (ESI): calcd for $\left[\mathrm{C}_{18} \mathrm{H}_{21} \mathrm{ClO}_{5}+\mathrm{Na}^{+}\right]$: 375.0970 , found: 375.0953 .

\section{Conflicts of interest}

There are no conflicts of interest to declare.

\section{Acknowledgements}

We thank the National Natural Science Foundation of China (21272271) for financial support and Chengdu Zhenhua BioTech Co., Ltd for supplying the waste liquids of producing 16dehydropregnenolone acetate from diosgenin.

\section{References}

1 (a) P. T. Anastas and J. C. Warner, Green Chemistry: Theory and Practice, Oxford University Press, 1998; (b) P. J. Dunn, A. S. Wells and M. T. Williams, Green Chemistry in the Pharmaceutical Industry, Wiley-VCH, Weinheim, 2010; (c) P. J. Dunn, Chem. Soc. Rev., 2012, 41, 1452; (d) J. Clark, R. Sheldon, C. Raston, M. Poliakoffd and W. Leitner, Green Chem., 2014, 16, 18-23; (e) D. Kralisch, D. Ott and D. Gericke, Green Chem., 2015, 17, 123-145.

2 (a) Catalytic Process Development for Renewable Materials, ed. P. Imhof and J. C. van der Wal, Wiley-VCH, Weinheim, 2013;

(b) P. Gallezot, Green Chem., 2007, 9, 295-302; (c) R. A. Sheldon, Green Chem., 2014, 16, 950-963.

3 Oxidative degraduation of diosgenin, tigogenin and rockogenin, etc. generates $(R) \mathbf{- 1}$, while sarsasapogenin and yamogenin give $(S)-\mathbf{1}(a)$ A. Goswami, R. Kotoky, R. C. Rastogi and A. C. Ghosh, Org. Process Res. Dev., 2003, 7, 306-308; (b) W. Tian, X. Xu, S. Liu, J. Shen and X. Wu, US Pat. 2006/0166955, 2006.

4 ChengguZhenhua Bio-Tech Co., Ltd who produce more than 400 tons of 16-dehydropregnenolone acetate each year from diosgenin by oxidative degradation, but never recover any $(R)-\mathbf{1}$.

5 A few examples to utilize $(R)$ - and $(S)-\mathbf{1}$ as starting materials in the synthesis of bioactive compounds have been reported.(a) T. Suzuki, K. Usui, Y. Miyake, M. Namikoshi and M. Nakada, Org. Lett., 2004, 6, 553-556; (b) S. Yu, X. Pan, X. Lin and D. Ma, Angew. Chem., Int. Ed., 2005, 44, 135-138; (c) Z. Wang, Q. Xu, W. Tian and X. Pan, Tetrahedron Lett., 2007, 48, 7549-7551; (d) K. Takahashi, K. Komine, Y. Yokoi, J. Ishihara and S. Hatakeyama, J. Org. Chem., 2012, 77, 7364-7370; (e) S. Zhang, H. Dong, J. Gui and W. Tian, Tetrahedron Lett., 2012, 53, 1882-1884; (f) J. Cao and P. Perlmutter, Org. Lett., 2013, 15, 4327-4329; $(g)$ J. Shen, Y. Shi and W. Tian, Chin. J. Chem., 2015, 33, 683-685.

6 (a) G. Erkel, H. Belahmer, A. Serwe, T. Anke, H. Kunz, H. Kolshorn, J. C. Liermann and T. Opatz, J. Antibiot., 2008, 61, 285-290; (b) J. Richter, L. P. Sandjo, J. C. Liermann, T. Opatz and G. Erkel, Bioorg. Med. Chem., 2015, 23, 556-563.

7 (a) J. Tauber, M. Rohr, T. Walter, G. Erkel and T. Opatz, Org. Biomol. Chem., 2015, 13, 7813-7821; (b) J. Tauber, K. Rudolph, M. Rohr, G. Erkel and T. Opatz, Eur. J. Org. Chem., 2015, 3587-3608.

8 J. Tauber, M. Rohr, T. Walter, D. Schollmeyer, K. RahnHotze, G. Erkel and T. Opatz, Org. Biomol. Chem., 2016, 14, 3695-3698.

9 V. Kovalenko and E. Matiushenkov, Tetrahedron: Asymmetry, 2012, 23, 1393-1399.

10 J.-L. Giner, Tetrahedron Lett., 2002, 43, 5457-5459.

11 A. De Mico, R. Margarita, L. Parlanti, A. Vescovi and G. Piancatelli, J. Org. Chem., 1997, 62, 6974-6977.

12 A. deMeijere, H. Winsel and B. Stecker, Org. Synth., 2005, 81, 14-25. 